\title{
Coupled thermo-hydro-mechanical behaviour of a deep clay
}

\author{
Núria Sau ${ }^{1,2}$, Enrique Romero ${ }^{1,2 *}$, and Hervé Van Baelen ${ }^{3}$ \\ ${ }^{1}$ Universitat Politècnica de Catalunya, Barcelona, Spain \\ ${ }^{2}$ Centre Internacional de Mètodes Numèrics en Enginyeria, Barcelona, Spain \\ ${ }^{3}$ ONDRAF/NIRAS, Brussels, Belgium
}

\begin{abstract}
An experimental study on Ypresian clays - one of the potential deep formations in Belgium for the geological disposal of heat-emitting radioactive waste- was undertaken to systematically study its thermal properties and coupled hydro-mechanical response during fast heating pulse tests. An accurate characterisation of the thermal properties is required for assessing the near-field perturbations around disposal galleries that the sedimentary host rock formation will undergo. A new experimental cell adapted to apply the high in situ stresses and with thermal flux sensors was used to directly measure the thermal conductivity at different sample orientations (heat flux orthogonal and parallel to bedding planes). A clear influence of the degree of saturation - despite being close to saturation - and anisotropic features on thermal conductivity have been detected. The study was complemented by performing fast heating pulse tests under constant volume on a new and fully-instrumented axisymmetric cell. The cell allowed recording the pore pressure build-up and dissipation along a heating pulse and under water-undrained conditions.
\end{abstract}

\section{Introduction}

An adequate characterisation of the thermal properties and coupled thermo-hydro-mechanical response of soils and rocks is required in energy geotechnics, particularly in the design of energy geo-structures, energy geostorage and deep geological disposal of heat-emitting radioactive waste [1-4].

Within the context of radioactive waste repositories, the following deep sedimentary clay host formations are currently considered: Boom Clay / Ypresian clays (Belgium), Opalinus Clay (Switzerland) and CallovoOxfordian Clay (France). In some of these formations, in situ heating tests have been already used to detect the thermal impact and determine the thermal conductivity by back-analysis $[5,6]$. Nevertheless, in deep Ypresian clays -one of the potential deep formations in Belgium for the geological disposal of heat-emitting radioactive waste-, in which no underground facility has been excavated, laboratory tests on well-preserved samples are mandatory. One of the main challenges when testing Ypresian clays is to restore the high in situ stresses at the depths of retrieval before thermal testing. This way, opening of fissures and gaps along bedding planes during retrieval, which affect the correct determination of the thermal conductivity, are minimised [7].

Thermal loads also induce pore water pressure buildup. This increase in pore pressure may compromise the stability of the galleries in deep repositories, since it may lead to shear failure or hydraulic fracturing. The thermalinduced pressurisation is a consequence of the difference between the higher thermal expansion coefficient of the pore fluid and that of the pore volume, in which the compressibility of the pore fluid and the compressibility of the pore volume -associated with the drained compressibility of the porous material- play an important role as shown by [8]. There is a large variability of the thermal pressurisation coefficient depending upon the nature of the material -associated with the stress-state dependency and induced damage affecting its drained compressibility - as well as on the range of the temperature change - the fluid thermal expansion is temperature-dependent. For example, values of the thermal pressurisation coefficient on heating between 0.06 and $0.192 \mathrm{MPa} /{ }^{\circ} \mathrm{C}$ have been reported for Boom Clay by [9] and [10], respectively. Table 1 summarises different theoretical and experimental values of the thermal pressurisation coefficients $\Lambda\left(\mathrm{MPa} /{ }^{\circ} \mathrm{C}\right)$ for different geomaterials. The evaluation of the coefficient is usually performed by back-analysis of in situ or laboratory tests [11-15] or directly determined by laboratory experiments $[8,10,16,17]$.

The current paper presents selected thermal results of an extensive experimental study performed on Ypresian clays using novel experimental setups. The objective of the study is threefold and focusses on:

a) measuring the thermal conductivity and studying the effects of the anisotropy and the initial degree of saturation of the samples - soils may undergo high suctions on deep retrieval that induce bedding opening and the loss of full saturation;

b) determining the specific heat of intact soil samples using a new temperature-instrumented stainless-steel container immersed in a calorimeter; and

\footnotetext{
* Corresponding author: enrique.romero-morales@upc.edu
} 
c) presenting fast heating pulse tests under soil constant volume and water undrained conditions to determine the evolution of the thermal pressurisation coefficient along heating paths.

Table 1. Summary of thermal pressurisation coefficients for different geomaterials.

\begin{tabular}{|l|c|c|}
\hline \multicolumn{1}{|c|}{ Material } & $\Lambda\left(\mathrm{MPa}^{\circ} \mathrm{C}^{-1}\right)$ & Ref. \\
\hline Boom Clay & 0.060 & {$[9]$} \\
\cline { 2 - 3 } & $\begin{array}{l}0.192 \text { (on heating) } \\
0.109 \text { (on cooling) }\end{array}$ & {$[10,18]$} \\
\hline Ypresian clays & $\begin{array}{l}0.066 \text { (on heating) } \\
0.030 \text { (on cooling) }\end{array}$ & {$[18]$} \\
\hline Opalinus claystone & 0.10 & {$[16]$} \\
\hline $\begin{array}{l}\text { Callovo-Oxfordian } \\
\text { Clay }\end{array}$ & 0.063 to 0.145 & {$[17]$} \\
\hline Kayenta sandstone & 0.59 & {$[12]$} \\
\hline Rothbach sandstone & 0.25 to 0.025 & {$[8]$} \\
\hline Clayey fault gouge & 0.10 & {$[15]$} \\
\hline $\begin{array}{l}\text { Intact rock at great } \\
\text { depth }\end{array}$ & 1.5 & {$[11]$} \\
\hline
\end{tabular}

\section{Material tested}

Tests were performed on Ypresian clays retrieved at depths between 335 and $390 \mathrm{~m}$ at Kallo (Belgium). Ypresian clays is a thick sequence of dominantly finegrained marine sediments deposited during the Ypresian Age (oldest age of the Eocene Epoch spanning the time between 56 to $47.8 \mathrm{Ma}$ ). The Ypresian clays at these depths present around $43.4-55.7 \%$ clay minerals, which are dominated by smectite $(23.0-29.5 \%$ in bulk) and illite $(12.0-18.1 \%$ in bulk). Non-clayey fraction is mainly constituted by quartz (33.1-39.3\%), alkali feldspar (2.9$6.0 \%)$ and plagioclase $(2.8-5.6 \%)$ [19]. Table 2 summarises the soil properties, as well as the initial state of the samples.

Table 2. Properties and initial state of Ypresian clays.

\begin{tabular}{|l|c|}
\hline \multicolumn{1}{|c|}{ Soil properties } & $\begin{array}{c}\text { Kallo } 1 \text { site, several cores } \\
\text { (depth: } 335 \text { to } 390 \mathrm{~m} \text { ) }\end{array}$ \\
\hline Bulk density, $\rho$ & $1.88-2.14 \mathrm{Mg} / \mathrm{m}^{3}$ \\
\hline Water content, $w$ & $17.5-28.2 \%$ \\
\hline Initial total suction, $\psi$ & $2.29-3.23 \mathrm{MPa}$ \\
\hline Density of solids, $\rho_{s}$ & $2.70-2.73 \mathrm{Mg} / \mathrm{m}^{3}$ \\
\hline Void ratio, $e$ & $0.500-0.840$ \\
\hline Degree of saturation, $S_{r}$ & $82.5-98.8 \%$ \\
\hline Particle sizes $<40 \mu \mathrm{m}$ & $81.5-99.8 \%$ \\
\hline Particle sizes $<2 \mu \mathrm{m}$ & $26.5-55.7 \%$ \\
\hline Liquid limit, $w_{L}$ & $61.3-154 \%$ \\
\hline Plasticity index, $P I$ & $38.3-127 \%$ \\
\hline
\end{tabular}

The Ypresian clays at the depth of interest display multi-modal pore size density functions obtained with mercury intrusion porosimetry on freeze-dried samples and with dominant entrance pore modes at $20 \mathrm{~nm}, 80$ $100 \mathrm{~nm}$ and $0.8-1 \mu \mathrm{m}$.

Measurements of the degree of saturation showed that Ypresian clays were not fully saturated after retrieval. This fact was associated with the large matric suction induced on water undrained retrieval [7]. These high matric suctions -usually over $2 \mathrm{MPa}$ - cannot be sustained under saturated conditions due to the relatively low air-entry value of the material associated with the largest pore mode (air-entry value around 0.40 $\mathrm{MPa}$ ). Consequently, and despite the careful sampling and trimming, some air was expected to enter the soil during retrieval, which induced the degree of saturation to decrease and fissures/gaps along bedding planes to open.

\section{Experimental programme and results}

\subsection{Thermal conductivity tests}

\subsubsection{Thermal conductivity cell}

A new experimental setup prepared to apply high stresses (up to $4 \mathrm{MPa}$ ) with a rigid PEEK $^{\mathrm{TM}}$ cell [20] was used to directly measure the thermal conductivity at different sample orientations (heat flux orthogonal and parallel to bedding planes). The high vertical stresses were required to restore in situ effective stress conditions (between 3.4 and $3.9 \mathrm{MPa}$ ) before the thermal tests -thus avoiding bedding planes to open. The cell was designed to apply a controlled high temperature (around $60^{\circ} \mathrm{C}$ ) at the top of a cylindrical specimen $(38 \mathrm{~mm}$ in diameter and $40 \mathrm{~mm}$ high). Several thermocouples monitored the temperature inside the soil and at the top and bottom heat flux sensors. Figure 1 shows a cross-section of the thermal cell. Two heat flux sensors with reference materials (a polycarbonate disc with $\lambda_{\text {poly }}=0.20 \mathrm{Wm}^{-1} \mathrm{~K}^{-1}$ and thickness $t_{\text {disc }}=1 \mathrm{~mm}$ placed between two highly conductive aluminium discs with $209 \mathrm{Wm}^{-1} \mathrm{~K}^{-1}$ ) were used to determine the input $q_{\text {in }}$ and output $q_{\text {out }}$ heat fluxes. These top and bottom fluxes allowed determining radial heat losses $\Delta q / q_{i n}$. Heat fluxes were determined as

$$
q_{\text {in }}=\lambda_{\text {poly }} \Delta T_{\text {top }} / t_{\text {disc }} \text { and } q_{\text {out }}=\lambda_{\text {poly }} \Delta T_{\text {bot }} / t_{\text {disc }}
$$

where $\Delta T_{\text {top }}$ and $\Delta T_{b o t}$ are the temperature changes between aluminium discs on both top and bottom heat flux sensors.

A neoprene membrane was used to avoid water content loss. A PEEK ${ }^{\mathrm{TM}}$ ring was then placed around the sample with membrane to provide radial stiffness and thermal insulation. Thermal tests were carried out at constant vertical stress -vertical force was applied with a lever mechanism.

\subsubsection{Results and interpretation}

This section summarises the results determined with the new thermal cell under high vertical stresses and those 
obtained with the older setup [7]. The older thermal tests were performed at $350 \mathrm{kPa}$, once samples were preconditioned in a triaxial cell to ensure higher degrees of saturation and the closure of fissures and gaps along bedding planes $[7,20]$.

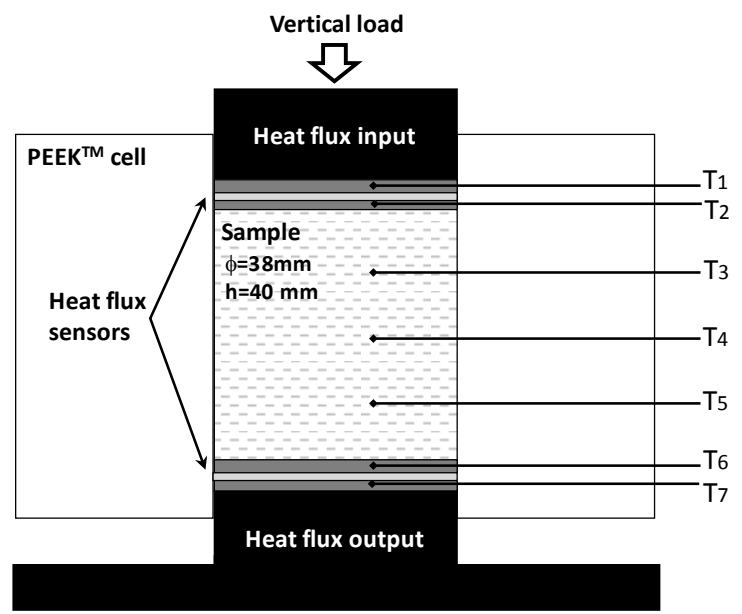

Fig. 1. Thermal conductivity cell with thermocouples $T i$.

The new thermal conductivity tests were performed at an average sample temperature close to $48^{\circ} \mathrm{C}$ and with a change in temperature across the sample around $25^{\circ} \mathrm{C}$. Testing times were kept as short as possible, usually 7 hours to reach steady-state, and thus avoid important water content losses. Figure 2 displays the time evolutions of temperatures during one of the new thermal conductivity tests. As observed in the figure, the thermal conductivity is not homogenous along the sample height (thermocouples $T_{2}$ to $T_{6}$ ), since temperature differences under steady-state conditions between equidistant points are not the same. As observed by [7], different phenomena contribute to explain these differences mainly associated with local soil volume and water content changes (final water contents were slightly lower close to the top cap at higher temperature).

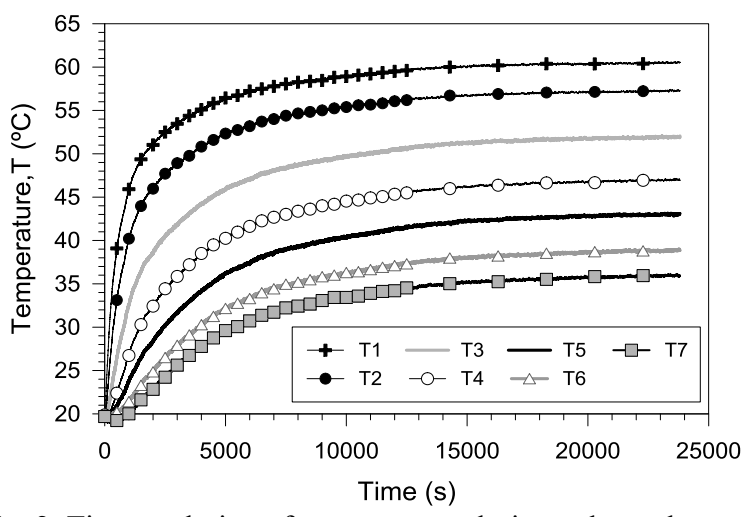

Fig. 2. Time evolution of temperatures during a thermal conductivity test.

Figure 3 displays the time evolution of the inflow and outflow heat fluxes. Radial heat losses are also indicated in the figure tending to $<10 \%$ under steady-state condition, which is approximately reached at elapsed times larger than $18000 \mathrm{~s}$. Under steady-state conditions, the global thermal conductivity $\lambda$ is computed using Fourier's law:

$$
\lambda=q_{a v e} L / \Delta T
$$

where $q_{\text {ave }}$ represents the average inflow and outflow heat fluxes, $L$ the sample height and $\Delta T$ the difference between temperatures $T_{2}$ and $T_{6}$.

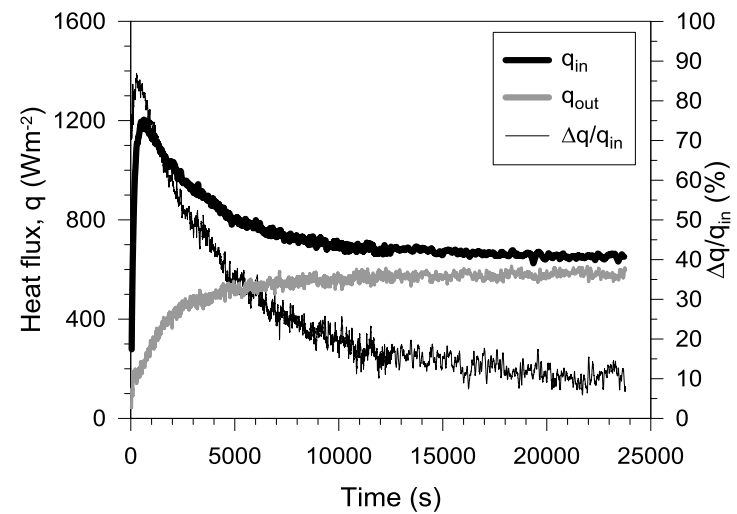

Fig. 3. Time evolution of heat fluxes $\left(q_{\text {in }}\right.$ and $\left.q_{\text {out }}\right)$ and radial losses $\left(\Delta q / q_{\text {in }}\right)$.

Figure 4 summarises the thermal conductivity results $v s$ the degree of saturation before the thermal tests using the old setup [7] and the new cell. Samples shown in this figure presented similar quartz content $33.1-39.3 \%$. The effects of quartz and clay content on the thermal conductivity have been studied by [20]. Two phenomena are clearly detected in the figure, the influence of the initial degree of saturation and anisotropic features. The data indicate the reduction in thermal conductivity with decreasing initial degree of saturation on both heat flux directions (orthogonal and parallel to bedding planes). Regarding anisotropic features, thermal conductivities determined with heat flow parallel to beddings planes $\lambda_{\|}$ are higher than those determined with heat flow orthogonal to bedding planes $\lambda \perp$, which is consistent with the observed anisotropic features of hydraulic conductivity [18]. Typical values close to saturation of $\lambda_{\|}$were around 1.90 to $2.15 \mathrm{Wm}^{-1} \mathrm{~K}^{-1}$, whereas $\lambda \perp$ were around 1.80 to $1.90 \mathrm{Wm}^{-1} \mathrm{~K}^{-1}$. Figure 4 also plots the back-analysed saturated thermal conductivity obtained by $[7,18]$ from a heating pulse test on Ypresian clays, which lies between the directly measured $\lambda / /$ and $\lambda \perp$.

\subsection{Specific heat tests}

\subsubsection{Specific heat setup}

The specific heat was determined by the method of mixtures. The assumption behind it is that when two bodies at different temperatures are mixed in a thermally isolated recipient (calorimeter), heat is transferred from the hot body (soil and container) to the cold body (water) until both bodies reach an equilibrium temperature. The specific heat setup includes a Dewar flask (calorimeter), 
four thermocouples to monitor the evolution of the temperatures during the transient phase and a magnetic stirrer to ensure a homogenous temperature distribution. A stainless steel container was designed to determine the specific heat of intact Ypresian clays [20], which prevented the loss of moisture during heating in the oven and the water to affect the sample when poured in the calorimeter. The container is constituted by a cylindrical body with top and bottom caps, one of them with a hole to insert a thermocouple in the soil sample. Another thermocouple monitored the temperature of the container.

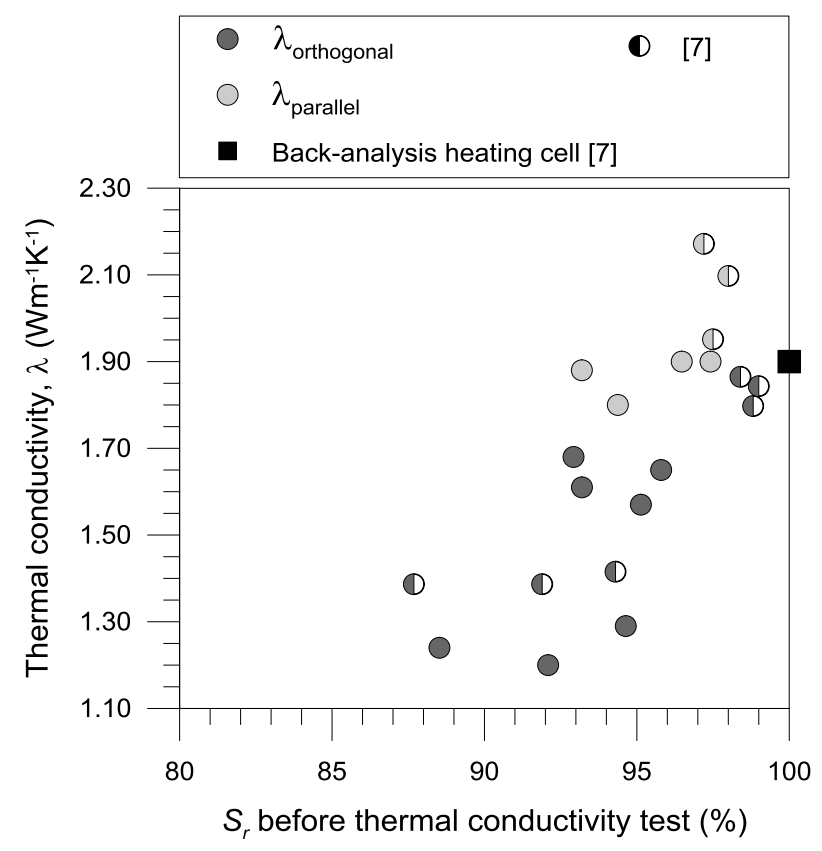

Fig. 4. Direct measurements of thermal conductivity for two different orientations (heat flux parallel and orthogonal to bedding planes) and back-analysed value from [7].

\subsubsection{Results and interpretation}

To determine the specific heat of the solid particles, a known mass of dry powder was heated in the oven up to $90^{\circ} \mathrm{C}$, and then poured inside the calorimeter with a known mass of water at ambient temperature. Finally, after stirring and waiting for steady-state conditions, the equilibrium temperature was reached. Since masses, temperatures and the specific heat of the water were known, the specific heat of the solid particles was determined. A calorimeter constant was considered in the calculations to quantify the heat capacity of the calorimeter (including the stirrer and the submerged part of the thermocouples). The specific heat of solid particles ranged between 841 and $922 \mathrm{~J} \mathrm{~kg}^{-1} \mathrm{~K}^{-1}$.

On the other hand, the procedure used to determine the specific heat of intact samples was slightly different. Figure 5 shows the time evolutions of temperatures for soil, container and water. After immersion of the container, a decrease in the temperatures of the soil and container was observed that induced an increase in the temperature of the water as heat was transferred. These data allowed determining the time evolution of the heat loss by the container $Q_{\text {out }}$ and the heat transferred to the water $Q_{i n}$, as shown in Figure 6 . The specific heat of the intact sample was computed by fitting the time evolution of total $Q_{\text {out }}$ (container and soil) to $Q_{i n}$. The specific heat ranged between 1604 and $1653 \mathrm{~J} \mathrm{~kg}^{-1} \mathrm{~K}^{-1}$. An important influence of the mineralogy and percentage of adsorbed water in the clayey fraction on the specific heat was also detected by [20].

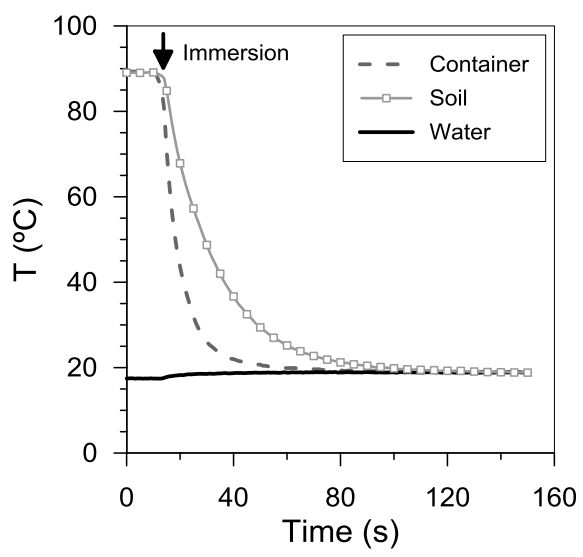

Fig. 5. Time evolution of temperature of water, soil and container during a specific heat test on intact soil sample.

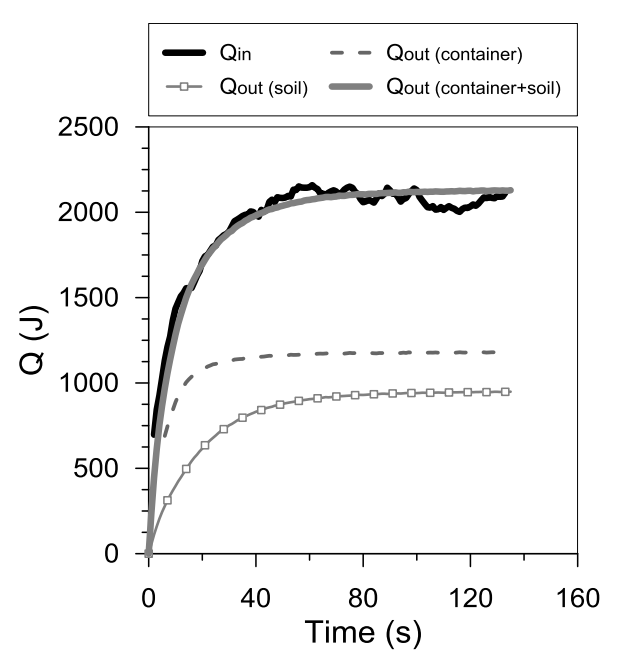

Fig. 6. Time evolutions of heat transferred during a specific heat test on intact soil sample.

\subsection{Heating pulse tests}

\subsubsection{Constant volume heating cell}

To evaluate the impact of non-isothermal paths on the hydro-mechanical response under constant volume and water undrained conditions, the heating cell developed by [16], updated by [18] and recently improved with total stress sensors by [20] was used. Figure 7 shows two schemes of the isochoric heating cell, which allows 
performing heating pulse tests with a heater $(\mathrm{H})$ installed along the axis of the sample in the lower part of the cell, and controlling hydraulic boundary conditions (top and bottom valves, $\mathrm{u}_{\mathrm{u}}$ and $\mathrm{u}_{\mathrm{b}}$ ) connected to two volume/pressure controllers. Pore water pressures $\left(\mathrm{Pw}_{1}\right.$ and $\left.\mathrm{Pw}_{2}\right)$, temperatures $\left(\mathrm{T}_{1}\right.$ and $\left.\mathrm{T}_{2}\right)$ and total stresses $\left(\mathrm{P}_{1}\right.$ $\mathrm{P}_{2}$ and $\mathrm{P}_{3}$ ) acting on the sample at the boundaries and at different heights of the soil sample $(75 \mathrm{~mm}$ in diameter and $100 \mathrm{~mm}$ high) were continuously monitored.
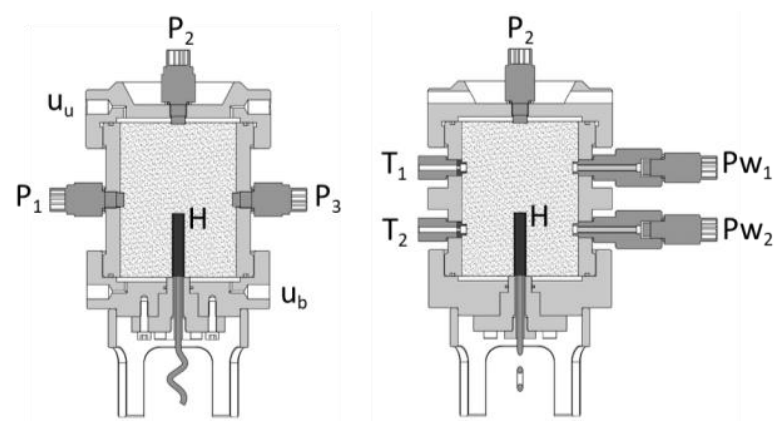

Fig. 7. Schemes of the improved isochoric heating cell with pore pressure transducers (Pwi), total stress sensors (Pi), thermocouples (Ti) and heater $(\mathrm{H})$.

\subsubsection{Results and interpretation}

The soil specimen was trimmed from a sample at depth $341 \mathrm{~m}$ with bedding planes orthogonal to the axis of symmetry of the heating cell (hydraulic flow orthogonal to bedding planes). The initial conditions of the soil specimen were $w=26.1 \%, e=0.740$ and $S_{r}=95.6 \%$. Therefore, an initial stage to restore full saturation was required before carrying out the heating pulses. A backpressure of $u_{b}=1 \mathrm{MPa}$ at the bottom drainage was initially applied, while the top drainage was kept under atmospheric conditions $u_{u}=0$. At the end of the stage, the water permeability was $2 \cdot 10^{-12} \mathrm{~ms}^{-1}$, which agrees with data reported by [18]. Afterwards, the top valve was closed to ensure an initial pore water pressure of $1 \mathrm{MPa}$ in the sample before the undrained heating and cooling paths.

The heating pulse was controlled by a temperature regulator, which allowed rapidly increasing the temperature up to $30^{\circ} \mathrm{C}$ and keeping it constant for around 24 hours. Afterwards, the heater was switched off to perform the cooling phase. The test ended when soil temperature reached $21^{\circ} \mathrm{C}$ (close to room temperature $\left.20.5^{\circ} \mathrm{C}\right)$.

Figure 8 shows the time evolution of pore water pressures and temperatures measured at the lateral boundaries during the heating and cooling phases. The evolution of heater and room temperatures are also included. The time evolutions of pore pressures at different heights were almost identical, indicating an adequate stiffness of the cell and a fully saturated condition of the sample. During the heating phase, pore pressures rapidly increased and then remained almost constant-except for a period in which room temperature fluctuations affected the temperature evolutions $T_{1}$ and $\mathrm{T}_{2}$ despite being the cell covered by a thermal insulation foam. Despite this fact, the evolutions of the pore pressures $\mathrm{Pw}_{1}$ and $\mathrm{Pw}_{2}$ correctly followed this thermal perturbation. During the cooling phase, pore pressures gradually reduced while temperatures decreased towards room conditions. Final pore pressures were lower than the initial ones -this may be associated with a small loss of water mass along the 1.5 days test.

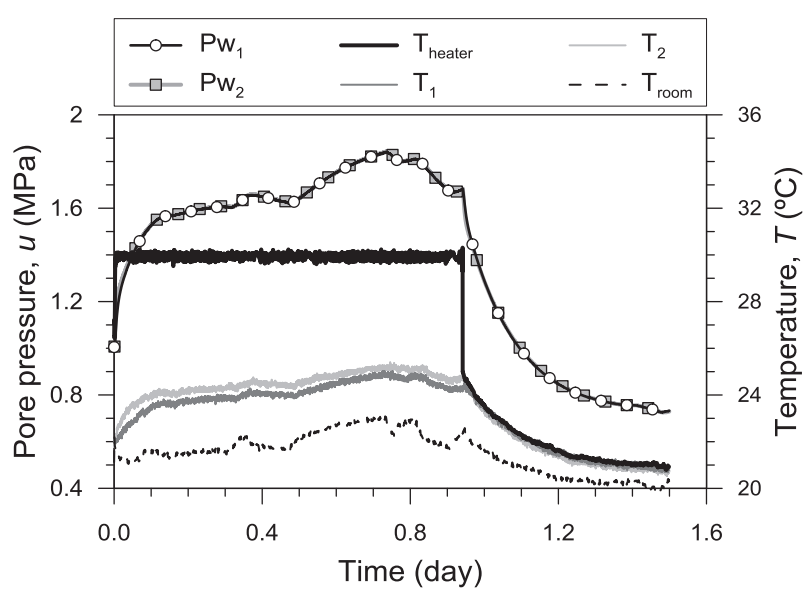

Fig. 8. Time evolution of pore water pressures $\left(\mathrm{Pw}_{\mathrm{i}}\right)$ and temperatures $\left(\mathrm{T}_{\mathrm{i}}\right)$, as well as room and heater temperature, during the heating and cooling stages. Isochoric heating pulse test at $30^{\circ} \mathrm{C}$ under water undrained conditions.

Figure 9 presents the time evolution of undrained pressurisation coefficients during the first 500 minutes of the heating phase. The results correspond to secant changes with respect to the initial temperature and pressure. The results should be interpreted as a boundary value problem particularly at the beginning of the test, when the pore pressure sharply increased-due to the stiffness of the system- and the temperatures at the lateral boundaries $T_{1}$ and $T_{2}$ were not stabilised. Therefore, these high values of the undrained pressurisation coefficients at early stages, which depend on the measurement points, are not totally representative. After $150 \mathrm{~min}$, these values stabilise at 0.25 and 0.35 $\mathrm{MPa}^{\circ} \mathrm{C}^{-1}$, depending on the measurement points. Higher values than those reported in Table 2 for the same clay on heating were obtained. However, to highlight these new fully undrained results, it should be emphasised that they were obtained under a very small range of temperature change (a temperature change of $9^{\circ} \mathrm{C}$ at the heater), compared to previous results [18] that were obtained at a larger temperature range of the heater $\left(39^{\circ} \mathrm{C}\right)$ and under controlled backpressure at the bottom boundary $(1.20 \mathrm{MPa})$. In addition, it is important to indicate that these values are higher than those reported for Boom Clay on heating $[10,18]$ and those presented in Table 2 for stiffer argillaceous formations (Opalinus claystone and Callovo-Oxfordian Clay). 


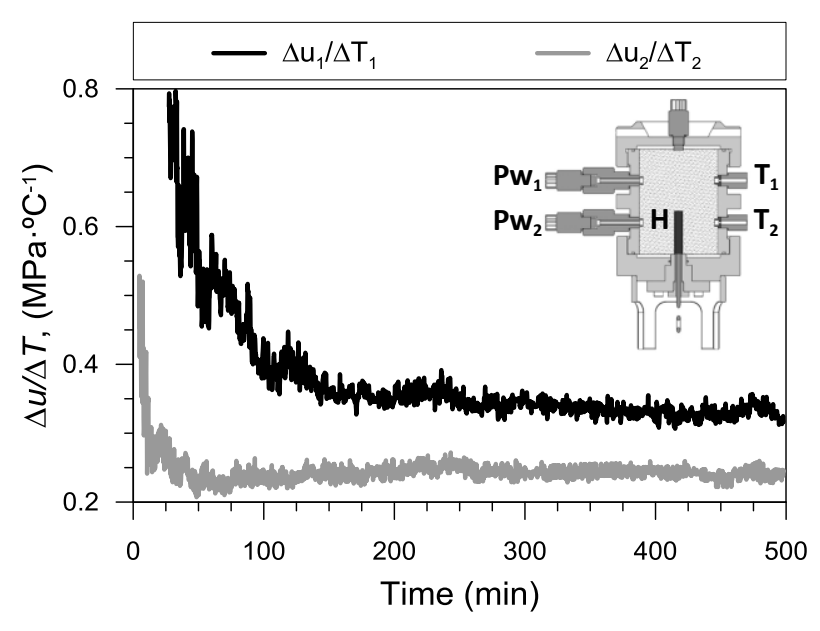

Fig. 9. Zoom of the time evolution of undrained pressurisation coefficients on heating at different measurement points.

\section{Concluding remarks}

An extensive laboratory campaign was performed to explore the thermal properties of Ypresian clays retrieved at a depth between 335 and $390 \mathrm{~m}$.

The thermal conductivity was determined at the high in situ stress conditions using a new experimental cell with heaters, $\mathrm{PEEK}^{\mathrm{TM}}$ ring to provide radial stiffness and thermal insulation, local measurements of temperature at different heights of the specimen, and two in-house manufactured heat flux sensors on top and bottom caps. High vertical stress during these thermal tests were required to ensure closure of fissures along bedding planes and restore high degrees of saturations. This was a critical experimental issue, since the thermal conductivities were shown to be affected by the initial degree of saturation, even for values above $90 \%$ saturation. Anisotropic features were detected, with higher thermal conductivity when heat flow was parallel to bedding planes ( 1.90 to $2.15 \mathrm{Wm}^{-1} \mathrm{~K}^{-1}$ close to saturation).

The specific heat of solid particles and intact soil sample was determined by the method of mixtures. A new stainless-steel container with two thermocouples was used to determine the specific heat of intact samples. The specific heat of these intact samples ranged between 1604 and $1653 \mathrm{~J} \mathrm{~kg}^{-1} \mathrm{~K}^{-1}$.

A new fully-instrumented heating cell -with thermocouples, total stress sensors and pore water pressure transducers- was used to determine the thermal pressurisation coefficient under water undrained and constant volume conditions. Time evolutions of pore water pressures and temperatures were presented along a heating-cooling path. Values of the thermal pressurisation coefficient on heating ranged between 0.25 and $0.35 \mathrm{MPa}^{\circ} \mathrm{C}^{-1}$, depending on the measurement point. These values were higher than those previously reported for Boom Clay and stiffer argillaceous formations (Opalinus claystone and Callovo-Oxfordian Clay).
Financial support of ONDRAF/NIRAS (Belgium) through different collaboration agreements with International Centre for Numerical Methods in Engineering (CIMNE, Spain) is greatly acknowledged ('Thermal aspects and their coupled HM effects on Ypresian clays and Boom Clay' CCHO 2016-0206/00/02).

\section{References}

1. K. D. Murphy, J. S. McCartney, and K. S. Henry, Acta Geotech. 10, 179 (2015)

2. J. E. Low, F. A. Loveridge, W. Powrie, and D. Nicholson, Acta Geotech. 10, 209 (2015)

3. A. Bidarmaghz, G. A. Narsilio, I. W. Johnston, and S. Colls, Geomech. Energy Environ. 6, 35 (2016)

4. Y. Dong, J. S. McCartney, and N. Lu, Geotech. Geol. Eng. 33, 207 (2015)

5. G. J. Chen, X. Sillen, J. Verstricht, and X. L. Li, Comput. Geotech. 38, 683 (2011)

6. B. Garitte, A. Gens, J. Vaunat, and G. Armand, Rock Mech. Rock Eng. 47, 111 (2014)

7. E. Romero, N. Sau, A. Lima, H. Van Baelen, X. Sillen, and X. Li, Geomech. Energy Environ. 8, 62 (2016)

8. S. Ghabezloo and J. Sulem, Rock Mech. Rock Eng. 42, 1 (2009)

9. I. Vardoulakis, Géotechnique 52, 157 (2002)

10. A. Lima, E. Romero, A. Gens, and J. Vaunat, Coupled Phenom. Environ. Geotech. 413 (2013)

11. A. H. Lachenbruch, J. Geophys. Res. 85, 6097 (1980)

12. V. V. Palciauskas and P. A. Domenico, Water Resour. Res. 18, 281 (1982)

13. J. R. Rice, J. Geophys. Res. Solid Earth 111, 1 (2006)

14. A. Gens, J. Vaunat, B. Garitte, and Y. Wileveau, Géotechnique 57, 207 (2007)

15. J. Sulem, P. Lazar, and I. Vardoulakis, Int. J. Numer. Anal. Meth. Geomech. 31, 523 (2007)

16. J. Muñoz, E. E. Alonso, and A. Lloret, Géotechnique 59, 293 (2009)

17. M. Mohajerani, P. Delage, J. Sulem, M. Monfared, A. M. Tang, and B. Gatmiri, Int. J. Rock Mech. Min. Sci. 52, 112 (2012)

18. A. França Lima Amorim, Thermo-HydroMechanical Behaviour of Two Deep Belgian Clay Formations: Boom and Ypresian Clays, Universitat Politècnica de Catalunya, PhD Thesis (2011)

19. G. Mertens and R. Adriaens, Analysis Report of the Bulk and Clay Mineralogy of 21 ON-Kallo-1 Samples (2018)

20. N. Sau, Thermo-Hydro-Mechanical Behaviour of Deep Argillaceous Formations, Universitat Politècnica de Catalunya, $\mathrm{PhD}$ Thesis (in preparation) 